\title{
Describing Physics Student Teachers' Orientations through Lesson Planning
}

\author{
Isik Saliha Karal \\ Faculty of Education, Giresun University, Turkey
}

Copyright $\bigcirc 2017$ by authors, all rights reserved. Authors agree that this article remains permanently open access under the terms of the Creative Commons Attribution License 4.0 International License

\begin{abstract}
Recent educational reforms realized in teacher education programs (TEPs) and secondary physics syllabus were aimed at placing the learning and teaching approaches in a constructivist framework. For this reason, student teachers in pre-service TEPs are expected to develop orientations adopting student-centred teaching approaches. The purpose of this study was to describe physics student teachers' science teaching orientations which can be defined as the general patterns of thought and behaviour related to physics teaching and learning. This case study explores 39 physics student teachers' orientations through lesson planning in their last academic term of TEP in the faculty of education. Student teachers' detailed lesson plans on a subject from secondary physics syllabus were used as data source and the data were analysed using content analysis to describe the participants' orientations. Findings show that more than half of the student teachers displayed student-centred orientations, clustered especially around activity-driven type of orientation; however some of them expressed their concerns about applicability of their lesson plans in inappropriate school environments and contexts.
\end{abstract}

Keywords Physics, Student Teacher (ST), Teaching Orientation

\section{Introduction}

Reforms and concerns about the quality of teaching and learning in science education in the world led to a variety of changes in the way of teaching and educating teachers [1, 2]. Thereby the reform attempts in science education and science teacher education call for a new way of thinking about the teaching and learning of science. In re-structuring science teacher education in 1997, development of teacher's knowledge levels and approaches to science teaching were targeted. The new national secondary physics syllabus has been put into practice in 2007, which required teachers to know and teach physics in a way the constructivist approach envisions. The secondary physics teaching syllabus gives priority to teaching methods detecting individual learning differences, including group workings in classroom and laboratory activities. These teaching methods are based on questioning and investigating (inquiry, discovery etc. used in the scientific research process) and conceptual change (analogies, conceptual change texts, and learning cycles). Another purpose of the syllabus is to improve student beliefs that would reinforce meaningful learning. That means the teacher-centred orientations of students formed in earlier schooling years are to change in the course of TEPs, hence the TEPs should meet the expectations of the secondary teaching syllabus. For these reasons these changes need to be examined and evaluated [3, 4], since this will eventually determine the success of any education reform $[5,6]$. In addition, understanding the beliefs and orientations of pre-service teachers contributes considerably to designing and revising pre-service training programs that lead to the optimal development of science teachers [7]. But very little was known about the implementation process of teacher education reforms and its results [2], and about the effect of TEPs on STs' orientations [3]. If teacher education is to be central to any teaching reform and to the quality of teaching and student learning, more research on teacher education reforms and their outcomes is needed [2, 8]. So, based on findings from empirical studies, relevant standards and policies can and continually are revised and refined [2, 4]. Thus, this study aimed via lesson planning, at describing physics TOs of STs being near the end of their TEP.

\section{Literature Review}

Research has shown that teachers' classroom practices and behaviours have been connected to their beliefs and knowledge about science teaching and student learning [7, 8]. These beliefs held by science teachers are formed during their earlier experiences as students $[8,9]$ and are considered as the critical components supporting the planning and implementation stages of instruction [10]. As STs and teachers engage in instruction in their field, these beliefs expand into their epistemological orientations [7]. Following [11, p.97]'s declaration of teachers' beliefs and orientations as a component of pedagogical content knowledge (PCK), 
teacher beliefs and orientations are again in the focus of research [12].

The orientation concept was first defined by [13] as the 'general patterns of thought and behaviour related to science teaching and learning' and having four types: activity-driven, didactic, discovery and conceptual-change. Then it was defined as 'teachers' knowledge and beliefs about the purposes and goals for teaching science at a particular grade level' and a 'general way of viewing or conceptualizing science teaching' by [11]. They extended the four orientations originally identified by [13], adding the orientations of process, academic-rigor, project-based science, inquiry and guided-inquiry and stated that teachers can hold multiple orientations depending on the topic or grade level they teach. [11] cautioned that a particular teaching strategy (e.g., use of laboratory) may be characteristic of more than one science teaching orientation (TO), stating that 'this similarity indicates that it is not the use of a particular strategy but the purpose of employing it that distinguishes a teacher's orientation to teaching science' (p.97). [14] reviewed this list of science TOs and classified them in two main categories: (a) teacher-centred orientations (didactic and academic rigor) and, (b) student-centred orientations based on the reform efforts or associated curriculum projects. She subdivided the latter category into orientations based on the reform efforts of the 1960s (process, activity-driven and discovery) and orientations based on contemporary reform efforts and curriculum projects (conceptual change, project-based science, inquiry and guided inquiry). However, limiting the teachers 'orientations to one or two ones defined by [11] may mask the teachers' main goals about teaching [3]. This is because the orientations cover also the emotional and general school objectives and a teacher may have more than one orientation bearing the core and peripheral objectives in mind. But in literature a number of researchers (15-17) used these categories as a quick fix and they chose to report only the orientation they thought dominant even if participants held characteristics of multiple orientations [18].

Studies related to teachers beliefs and orientations showed that STs joined to TEPs with some core and peripheral beliefs $[7,16]$. Core beliefs are more resistive to change and reflect a person's beliefs about what knowledge is, how it can be gained and in physics where teachers have in their formative years an experience of the powerful understanding of the physical world provided by these disciplines which have a permanent effect on their review of science and orientation $[7,19,20]$. This experience often leads to a 'traditional' view of science. Peripheral beliefs are related to individual learning such as learning strategies and are more likely to change depending on the particular learning context $[7,16,21]$. These peripheral beliefs may be formed in TEP during methodology courses but they may also change due to the nature of conditions in the course of time. Although TEPs have an effective role on the shape of STs' science TOs [22, 23], STs transform the ideas gained from methodology courses and teaching experiences into their personal PCK through their science conception, and eventually they manifest it in their science TO [19]. In fact, [24, 25] examined how STs' orientations develop at different periods of their TEP and concluded that STs entered the TEP with strongly held perceptions of teaching. Although STs gained additional views of the teachers' role, the core components of their science TOs were robust and did not change significantly throughout the program.

Therefore, the purpose of this study was to describe physics STs' science TOs. In this study orientations are interpreted in terms of general views of science in relation to typical patterns of teaching actions, not topic-specific knowledge, consistent with [13]'s definition of orientations. Using [11]'s orientation classification and [14]'s orientation grouping, the following research question was addressed to determine physics STs' orientations: Which orientations do physics student teachers near the end of teacher training program display?

\section{Materials and Methods}

The case study strategy providing intensive analysis of a bounded system was adopted to investigate the orientations of a group of physics STs.

\subsection{Participants}

Participants are 39 physics STs attending their last academic term of pre-service TEP. Table 1 shows the courses continuing throughout three academicterms related to pedagogy education of the participants.

Table 1. Courses in pedagogy education

\begin{tabular}{|c|c|c|c|}
\hline \multirow{2}{*}{$\begin{array}{l}\text { Subject Matter } \\
\text { Education }\end{array}$} & \multicolumn{3}{|c|}{ Pedagogy Education } \\
\hline & TERM I & TERM II & TERM III \\
\hline \multirow{5}{*}{$\begin{array}{l}\text { All SMK courses } \\
\quad(7 \text { terms })\end{array}$} & - $\quad$ Special Teaching Methods I & $\begin{array}{ll}\text { - Instructional Technology and Material } \\
\text { Design }\end{array}$ & - $\quad$ Field Study \\
\hline & 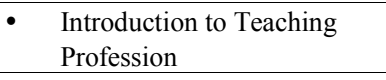 & - Special Teaching Methods II & $\begin{array}{ll} & \text { Examining Subject Matter } \\
& \text { Textbooks } \\
\end{array}$ \\
\hline & - Development and Learning & - Classroom Management & - $\quad$ Guiding \\
\hline & $\begin{array}{ll}\text { - } & \text { Planning and Assessment in } \\
& \text { Teaching }\end{array}$ & - School Experience II & - $\quad$ Teaching Experience \\
\hline & - $\quad$ School Experience I & - Elective & \\
\hline
\end{tabular}


STs in their pedagogy education are taught on frequently used science well known learning theories, the constructivist approach and learning cycle models. In pedagogy courses, STs form working groups and design various activities and teaching plans based on learning theories and models being taught. They also make presentations and share their works in the classroom using technological means and advantages and limitations of various teaching models, methods and techniques are discussed in these courses. In this way STs are expected to improve skills for selecting and applying effective methods and materials for their actual teaching, basically through micro-teaching activities.

\subsection{Instrument and Procedures}

Data were collected at the end of the pedagogy education. As mentioned in the literature, lesson plans proposed by STs on a preferred physics topic are effective data to capture their orientations [26] and the participants' lesson plans were used as data sources. Although data coming from a single-source can be seen problematic, some researchers used only interviews or lesson plans to describe the participants' orientations [7, 27]. This work aimed only at describing STs' existing orientations without considering any relation between their orientations and practices. For this purpose STs were asked to choose a concept from physics syllabus in which they felt qualified, and then to prepare a 40-minute lesson plan to teach the selected concept, describing clearly all activities to be carried out in the plans. Because an orientation is considered as a general view of science teaching, we did not limit the topics. In the second part of the data gathering instrument STs' assumptions and required conditions for this plan to be put into practice were asked. By this question we aimed at determining the factors which might have an effect on their orientations.

There was no time limitation in preparing lesson plans under the control of researcher. Time periods of up to 120 minutes and 4 to 6 pages were used by STs to write lesson plans. STs were not allowed to use any sources of SMK and to communicate with each other because orientations include the goals related to SMK.

\subsection{Data Analysis}

Document analysis, commonly referred to as content analysis, and involves the careful consideration of a series of related questions [28-29, p.207]. This method helps the researcher to analyse contents of any document [30]. It was used in evaluating the lesson plans which covers full details, such as SMK, equipment, technological means, teaching methods and techniques, usage of real-life context-based approaches or examples, questions to be used in assessment, determination of prior knowledge of students, identification and elimination of misconceptions, and the reasons of their various choices, of their teaching on selected topics, i.e. adhesion and cohesion, fission and fusion, properties of magnets etc.

Finally STs' orientations were determined in more details by analysing the instructional strategies they chose. As an example, the explanations related to why the method of $5 \mathrm{E}$ learning cycle model or the discovery model of Bruner is chosen in teaching strategies were evaluated first. Then work sheets, technological means, experimental equipment, group workings and explanations and roles of STs relevant to these activities used in the stages of learning cycles were analysed. The purpose of employing the specific teaching strategies [11] by STs was determined independently by the researcher at different times. For validity, raw data were presented as excerpts, for conformability the research process was made as clear as possible for the reader.

\subsection{Orientations of Physics Student Teachers}

As displayed in Table 2, six orientation types emerged from the analysis of lesson plans, while project-centred, inquiry, discovery and investigation orientations were not displayed.

\section{Findings}

Table 2 shows the orientation types and relevant number of STs: Activity-driven (17), academic rigor (10), didactic (8), guided-inquiry (2), conceptual change (1), process (1). The majority displayed didactic orientation focussing mainly on SMK, meaning that STs tried to transmit the facts of science to learners:

...in the second phase of Ausubel's learning theory much more information can be transmitted in a short time... (ST10).

On the other hand, STs displaying didactic orientation featured technological means, i.e. power-point software, videos, to enhance motivation, visualization and effective use of lesson time, as can be seen in the following excerpts:

Teaching the parallelogram methods within a single session can only be possible by using the verbal and power-point presentations. Blackboard should be used rarely since it uses the time up... (ST10).

Data analysis showed that the difference between STs displaying didactic orientations and academic rigor is the aim of using technological means, demonstration experiments and visual materials. The former group targeted to transmit knowledge faster while the later to engage students in activities:

For demonstration two students stretch the rope by two ends...one end is periodically moved up and down ... (ST5). 
Table 2. Orientations of physics student teachers

\begin{tabular}{|c|c|}
\hline Orientation and Characteristic of Instruction (number of STs) & Indicators of Orientations in Lesson Plans \\
\hline $\begin{array}{l}\text { Academic Rigor (10) } \\
\text { Students are challenged with difficult problems and activities, } \\
\text { such as laboratory work and demonstrations. }\end{array}$ & $\begin{array}{l}\text { A section from the cinema film is presented... The discussion is to get started... } \\
\text { Eggs are handed out to students and forces are applied to the eggs in the specified } \\
\text { direction and discussion is started about the strength of the crust... (ST4). }\end{array}$ \\
\hline $\begin{array}{l}\text { Didactic ( } 8) \\
\text { The teachers present information, generally through lecture or } \\
\text { discussion, and questions directed to students are to hold them } \\
\text { accountable for knowing the facts produced by science. }\end{array}$ & $\begin{array}{l}\text { Because the teacher uses verbal presentation, he can transfer more knowledge in a } \\
\text { short time... Teaching both the polygon and the parallelogram methods etc. } \\
\text { within a single session can only be possible by using the verbal presentation... } \\
\text { (ST10). }\end{array}$ \\
\hline $\begin{array}{l}\text { Conceptual Change (1) } \\
\text { Students are pressed for their views about the world and consider } \\
\text { the adequacy of alternative explanations. The teacher facilitates } \\
\text { discussion and debate necessary to establish valid knowledge } \\
\text { claims. }\end{array}$ & $\begin{array}{l}\text { There is a misconception that temperature and heat are the same things... } \\
\text { Questions related to these concepts are directed to the students to start } \\
\text { discussions... An experiment is done...prepared conceptual change texts are } \\
\text { handed out to students... (ST2). }\end{array}$ \\
\hline $\begin{array}{l}\text { Process (1) } \\
\text { Teacher introduces students to the thinking processes employed by } \\
\text { scientist to acquire new knowledge. Students engage in activities } \\
\text { to develop thinking process and integrated thinking skills. }\end{array}$ & $\begin{array}{l}\text { Students are divided into groups, a block, and a dynamometer is supplied to each } \\
\text { group...The teacher should prepare the students in doing experiments, recording } \\
\text { and interpreting data and drawing conclusions from a certain process (ST22). }\end{array}$ \\
\hline $\begin{array}{l}\text { Activity-Driven (17) } \\
\text { Students participate in "hands-on" activities used for verification } \\
\text { or discovery. }\end{array}$ & $\begin{array}{l}\text { Experiment groups weigh masses using a dynamometer and record results in a } \\
\text { table... (ST1). } \\
\text { Worksheet and experimental equipment are handed out to students ... (ST32). }\end{array}$ \\
\hline $\begin{array}{l}\text { Guided-Inquiry (2) } \\
\text { The teacher and students participate in defining problems, } \\
\text { inventing and testing explanations, data and conclusions. The } \\
\text { teacher scaffolds students efforts to use the material and } \\
\text { intellectual tools of science independently. }\end{array}$ & $\begin{array}{l}\text { Small groups of students are asked to prepare mixtures to be separated later due to } \\
\text { the magnetic and density properties of constituents...Groups are visited to check } \\
\text { whether they followed the required procedures or not...Questions are directed to } \\
\text { the failing groups which are guided to succeed...They are asked to make } \\
\text { hypothesis by discussing what they had done... (ST36) }\end{array}$ \\
\hline
\end{tabular}

The lesson plans displaying activity-driven orientation taking place in the second order focussed mainly on 'hands-on experiences' which requires students to be active with materials. STs displaying this orientation planned to teach using group working:

Form groups of 3 or 4 students. Hanging various objects from the dynamometer, measure the stretching and record this in a table. Explain the reason for this stretching... (ST1).

Following the presentation of all the materials and instructions and the realization of activities, STs planned to discuss student commentaries, made the necessary explanations, presented related mathematical equations and then moved to practical stage.

The process, the conceptual change and the guided-inquiry orientations were displayed by just a few STs. The goal of the process orientation of one ST was to help students develop 'process skills':

I should have the students think about various variables through performed activities...these activities should aim at providing the students with the skills of hypothesizing, doing experiments, recording and interpreting data and drawing conclusions... (ST22).

The goal of the conceptual change orientations is to facilitate the development of scientific knowledge by confronting students with contexts that challenge their naive conceptions. ST2 used methods and techniques such as learning circle, experiment, computer-based instruction, brain storming and conceptual change text to teach the concepts of heat and temperature and to eliminate misconceptions.
The teacher with a 'guided-inquiry' orientation might begin by engaging her class in the task of establishing a question or a problem in the related subject. ST displaying this orientation began teaching by mixing straw and wheat:

We mixed these but how could one separate one constituent from the other? (ST36).

Then the students are asked to separate this mixture using their prior knowledge and to form new separable mixtures using materials available in the lab:

If the students are found to prepare mixtures using only the magnetic properties of materials they are urged to take the density property into consideration as well (ST36).

The majority of STs displaying different orientations establish a connection between the physics subject and the university-entrance or other national competition examinations for the purpose of motivating the student:

To motivate the student it is said that he or she would most probably meet related questions in the life-changing university examination (ST11).

But in the subjects of waves, adhesion, cohesion and strength of materials which have minor importance in the entrance-to universities exam STs used examples from daily life to motivate students.

To motivate students I say 'When we look around us, we see that living things have different dimensions'... (ST4).

Project-centred, inquiry, discovery and investigation orientations were not displayed by any ST. But some STs requested investigation as homework for future lessons.

In summary, the lesson plans showed that about half of the 
STs displayed teacher-centred orientations (didactic and academic rigor). The other half displayed student-centred orientations based on the reform efforts of the 1960s and curriculum projects of 2000s (process and activity-driven, conceptual change and guided inquiry). More than half of STs displaying student-centred orientations adopted the activity-driven orientation of 1960 s.

\subsection{Contextual Requirements Proposed by STs to Apply Lesson Plans}

As can be seen in Table 3, seven themes emerged from the data analysis for the applicability of lesson plans prepared by STs.

STs who pointed at the material facilities of the school to be essential requirements, displayed student-centred as well as teacher-centred orientations. STs displaying teacher-centred orientations stressed that they did so because they needed to use technological means, such as power-point software, for presentation of information and videos for demonstration of experiments. ST5 who displayed academic rigor orientation and used easily accessible material such as a wave string did not mention any necessity of equipment, but he put emphasis on the internet connection and computer facilities for animations and simulations in the web. ST5 argued that if a computer and a projector were not available, activities to teach the subject well would not be successful:

Today our classrooms still using traditional methods and lacking the required experimental equipment do not facilitate the use of lesson plans prepared on the basis of the constructivist point of view'(ST5).

According to ST20, a teacher should adopt student-centred teaching approaches to apply his lesson plan: "Teacher should adopt the constructivist approach to apply the plan and should possess sufficient SMK."
Students' prior knowledge and teachers' SMK were declared as other basic requirements for the applicability of the lesson plans. STs emphasised that the teacher and the students should possess knowledge of subject at a certain level to realize the desired activities. The importance of teachers' SMK is emphasized by those who possess both teacher-centred didactic (ST9, 21, 31) and academic rigor (ST27) and student-centred activity-driven (ST19, 20) orientations. Together with student prior knowledge, student motivation is also considered as an important component of successful application of the plans. According to ST39, student motivation and behaviours caused difficulties in the application of student-centred activities:

Hum and noise arise whenever an activity gets start. It takes time to draw students' attention and restore silence. The main cause is that students had no laboratory culture... Students should be given laboratory habits from the first years (ST39).

A small number of STs displaying student-centred orientations also expressed that teachers' guidance and students' active participation in experiments are essential to realize the lesson plan. Five STs displaying activity-driven orientation and doing activities with easily-accessed simple equipment wrote that their plans could be applicable to any situation. Three STs whose plans did not contain any experimental activity displayed academic rigor. But most of the STs preparing lesson plans according to student-centred approaches emphasised that their lesson plans would be applicable when conditions permitted.

In summary, most of the STs stated that some conditions should be met for their lesson plans to be applicable, while 8 of them expressed that no special conditions were necessary to apply their lesson plans.

Table 3. Contextual requirements asserted by STs to apply lesson plans

\begin{tabular}{|c|c|}
\hline $\begin{array}{c}\text { Requirements } \\
\text { (Number of STS) }\end{array}$ & Excerpts \\
\hline $\begin{array}{l}\text { SMK and Knowledge of Method of } \\
\text { STs (8) }\end{array}$ & $\begin{array}{l}\text { STs should have the general knowledge and SMK to be able to give examples from daily-life and to apply } \\
\text { activities (ST31). }\end{array}$ \\
\hline $\begin{array}{l}\text { Experimental and computational } \\
\text { facilities (23) }\end{array}$ & $\begin{array}{l}\text { If a computer and the internet are not available in the classroom, this activity that I believe will make the } \\
\text { subject understandable cannot be realized (ST5). } \\
\text { The existence of equipment needed for the experiment is important (ST14). }\end{array}$ \\
\hline Student Motivation (6) & $\begin{array}{l}\text { Students must be motivated (ST30). } \\
\text { There must be a suitable classroom environment and students must be ready to get the information (ST21). }\end{array}$ \\
\hline Enough Time (2) & $\begin{array}{c}\text { For activities in schools an excess time of twenty minutes should be given (ST31). } \\
\text { This plan may not be completed in one session (ST9). }\end{array}$ \\
\hline Support of School Administration (1) & $\begin{array}{l}\text { Seminars should be held for the administrators to recognise the importance of teaching activities and to help } \\
\text { teachers (ST31). }\end{array}$ \\
\hline Students' prior knowledge (9) & $\begin{array}{l}\text { There should not be any lack of basic knowledge of the student about this subject. The teacher can uncover } \\
\text { this knowledge but this may take time (ST26). }\end{array}$ \\
\hline Number of Students in the class (6) & $\begin{array}{l}\text { Number of students in the class is important for the students' active participation and for the teacher's } \\
\text { guidance (ST26). } \\
\begin{array}{r}\text { Since group working and giving an opportunity of talking to every group are necessary, the class should not } \\
\text { be over crowded (ST28). }\end{array}\end{array}$ \\
\hline Applicable in every condition (8) & $\begin{array}{l}\text { Difficulties in supplying the experimental equipment may arise, in such a case data-show presentation can } \\
\text { be used, if this is not available oral presentation with drawings on the blackboard can be done (ST35). }\end{array}$ \\
\hline
\end{tabular}




\section{Discussion and Conclusions}

In this work the determination of the orientations of [11]'s classification displayed by physics STs at the end of the TEP was aimed at, because changing national secondary teaching syllabus requires transformation of STs' orientations in TEP and adoption of essentially student-centred orientations. Findings showed that 21 STs displayed student-centred and 18 STs teacher-centred orientations. A $16 \%$ difference on behalf of student-centred orientation may at first not be considered quiet meaningful. But if one remembers that these STs were coming through the conventional teacher-centred education and were expected to repeat overwhelmingly this type of orientation, the ratio of $21 / 18$ points to an important transformation, since [23]'s and [4]'s research showed the effect of the TEPs on shaping the STs' orientations. For instance, the adoption of activity-driven orientation by the majority of STs displaying student-centred orientation seems to meet the expectations of the student-centred and activity-based national secondary physics syllabus. On the other hand the fact that nearly half of the STs maintained the teacher-centred orientation suggests the existence of some other factors. Firstly, the teacher educators generally continue lecturing traditionally while emphasising reformist approaches. Another factor is that in-service physics teachers mentoring STs in high schools are compelled to use didactic manners due to student demands of becoming competent in examinations permitting entrance to higher education. In these classes the available average time of two hours for physics is used to solve as many problems as possible instead of performing student-centred activities such as experiments and group workings. Time limitation, crowded classes, board exams and current school context also had much influence in shaping teachers' science TOs, generally the teacher-centred ones [3]. Some of the STs adopting student-centred orientations had serious doubts about the applicability of reformist suggestions in the present-day secondary schools because they thought the learning environment and assessment systems, including university-entrance examinations vital in motivating students, did not match with those of constructivist approaches. But the success of educational reforms depends on the support or hindrance to orientations of teachers at the beginning of their career [8]. So and so, the requirements of most STs show that their teaching can vary with a number of factors such as the characteristics of students and schools, SMK and the technological skills of STs. [31] argued that beliefs, applications and orientations of beginning teachers are more flexible and can be changed by factors such as students, teachers, programs and school environment. The excerpt of ST5 in Table 3 supports the statement, due to [32], 'if the context is not suitable for the teachers after they graduate from TEPs, they may not perform their constructivist beliefs in their profession and go back to traditional beliefs after some time'. According to the expression by ST35 in Table
3 , there is a probability that student-centred orientations can be replaced by a teacher-centred one due to contextual conditions; especially the pre-service secondary science teacher's belief orientations are unstable and have a tendency to change $[4,7]$. This shows that these peripheral beliefs formed by methodology courses in TEP are not as resistant to change as core beliefs formed in teacher's formative years and considered as the traditional view of science $[7,19,20]$.

This study show that a noticeable section of STs still displayed teacher-centred orientations at the end of the TEP and the reforms made in teacher education and secondary physics syllabus have not been successful at the desired level. Because STs have already had various pre-conceptions before they entered the TEP $[25,33]$ and turning STs' existing beliefs into beliefs required by the reform packet is difficult [32]. In the analysis of formation of STs' ideologies about teaching influences of teacher trainers should primarily be taken into consideration because STs observed them and were inspired by them throughout training [23]. It is known that teaching at the university level was essentially run didactically in contrast to the constructivist instructions. If learning through constructivist instructions is to be realized in today's schools, university physics and pedagogy courses must be run in such a way that STs could live through it [15]. But inconsistencies between teacher educators' discourses or expectations and their practices in our TEP and physics teachers tend to teach as they were taught [34] may cause STs to fail in the internalization of constructivist teaching [32]. For example some STs displaying teacher-centred orientation stated that they use $5 \mathrm{E}$ learning cycle to have students participate to lesson actively. But when the stages of $5 \mathrm{E}$ learning cycle were examined in their plans, it is seen that students of the class were not assigned active roles in any stage of 5E, only the SMK to be submitted was divided into 5E stages. This shows that STs tried to satisfy the expectations of teacher educators based on the constructivist approaches, but they had difficulties in internalization of constructivist teaching because they acquired teacher-centred orientations in the past as students.

\section{Implications and Limitations}

Because orientations cover not only the goals related SMK but also the emotional and general school objectives, science STs and teachers may have multiple orientations based on core and peripheral objectives [3,18]. But some researchers $[16,26]$ prefer to highlight only the orientation which is considered dominant and this is the approach followed in this study. Actually, there is a possibility that STs have more than one orientation because some STs stated that if he/she chose another subject he/she would use different teaching methods. By permitting choosing the subject we assumed that STs would prepare the lesson plan in accordance with their dominant orientation. Thus in our study each ST was essentially identified by one science TO, 
either student-centred or teacher-centred.

The sample in this study consisted of STs who were at the last stage, the three-semester pedagogical education, of the TEP and made observations in practice schools during the first two semesters within these cope of courses School Experience I, II and taught in the classroom as required by the course Teaching Experience in third semester. There is a possibility that STs' orientations were affected by the difficulties they faced in practising schools which use traditional teaching methods and at which STs were trying to implement their qualifications in constructivist approaches gained through methodology courses taken prior to teaching experience. Therefore, taking the effect of teaching experience into account in planning future studies on examining the effect of TEP on STs' orientations is recommended.

From methodological perspective, it is worth stressing here that STs' orientations towards physics teaching would be more accurately defined by using multi-methods such as observing STs' micro-teaching or actual class teaching practices, analysing their reflective journals about their practice and interviewing with them by expending more time and effort.

\section{REFERENCES}

[1] S. Feimen-Nemser. Teacher preparation: Structural and conceptual alternatives. In J. Sikula (Ed) Handbook of Research on Teacher Education (2nd ed., pp.212-233). New York: Macmillan Publishing Company. 1990.

[2] J. Wang, S.J. Odell, C.L. Klecka, E. Spalding, E. Lin. Understanding teacher education reform. Journal of Teacher Education, Vol.61, No.5, 395-402. 2010.

[3] P.M. Friedrichsen, T.M. Dana. Substantive-level theory of highly regarded secondary biology teachers' science teaching orientations. Journal of Research in Science Teaching, Vol.42, No.2, 218-244. 2005.

[4] V. Pilitsis, R.G. Duncan. Changes in belief orientations of pre-service teachers and their relation to inquiry activities. Journal of Science Teacher Education, Vol.23, No.8, 909-936. 2012.

[5] R. Cohen, A. Yarden. Experienced junior-high-school teachers' PCK in light of a curriculum change: "The cell is to be studied longitudinally" Research in Science Education, Vol.39, 131-155.2009.

[6] V. Nargund-Joshi, M.A Park Rogers, V.A. Akerson. Exploring Indian secondary teacher's orientations and practice for teaching science with respect to reform. Journal of Research in Science Teaching, Vol.48, No.6, 624-647. 2011.

[7] J.A. Luft, G.H. Roehring. Capturing science teachers' epistemological beliefs: The development of teacher's beliefs interview. Electronic Journal of Science Education, Vol.11, No.2, 38-63. 2007.
[8] K. Levitt. An analysis of elementary teachers' beliefs regarding the teaching and learning of science. Science Education, Vol.86, No.1, 1-22. 2001.

[9] I. Huibregtse, F. Korthagen, T. Wubbels. Physics teachers' conceptions of learning, teaching and professional development. International Journal of Science Education, Vol.16, No.5, 539-561. 1994.

[10] V. Nargund-Joshi, X. Liu. Understanding in-service teachers' orientation towards interdisciplinary science inquiry. National association for research in science teaching annual conference, Rio Grande, Puerto Rico. 2013.

[11] S. Magnusson, J. Krajcik, H. Borko. Nature, Sources and Development of Pedagogical Content Knowledge for Science Teaching, Gess-Newsome, J. and Lederman, N.G., (Ed.), "Examining Pedagogical Content Knowledge", London: Kluwer Academics Publishers. 1999.

[12] Nilsson, P. 2008. "Teaching for Understanding: The Complex Nature of Pedagogical Content Knowledge in Pre-service Education". International Journal of Science Education, Vol. 30, No.10, 1281-1299.

[13] C. W. Anderson, E. L. Smith. Teaching science. In V. Richardson-Koehler (Ed.), Educators' handbook: A research perspective (pp. 84 -111). New York: Longman. 1987.

[14] P.M. Friedrichsen. Substantive-level theory of highly regarded secondary biology teachers' science teaching orientations. Unpublished doctoral dissertation, The Pennsylvania State University, University Park. 2002.

[15] M.J. Volkman, S.K Abell, M. Zgagacz. The challenges of teaching physics to pre-service elementary teachers: Orientations of the professor, teaching assistant, and students. Science Education, Vol.89, 847-869. 2005.

[16] C.V. Schwartz, Y. Gwekwerere. Using a guided inquiry and modelling instructional framework (EIMA) to support pre-service K-8 science teaching. Science Education, Vol.91, 158-186. 2007.

[17] V. Kind. Preservice science teachers' science teaching orientations and beliefs about science. Science Education, Vol.100, No.1, 122-152. 2016.

[18] P. Friedrichsen, J.H. Van Driel, S.K. Abell. Taking a closer look at science teaching orientations. Science Education, Vol.95, No.2, 358-376. 2011.

[19] A.M. Greenwood. Factors influencing the development of career-change teachers' science teacher orientation. Journal of Science Teacher Education, Vol, 14, No.3, 217-234. 2003.

[20] K.G. Witz, H. Lee. Science as an ideal: teachers' orientations to science and science education reform. Journal of Curriculum Studies, Vol.41, No.3, 409-431. 2009.

[21] J.M. Brownlee. Knowing and learning in teacher education: A theoretical frame work of core and peripheral beliefs in application. Asia-Pacific Journal of Teacher Education and Development, Vol.4, No.1, 131-155. 2001.

[22] S.K. Abell, L.A. Bryan. Reconceptualising the elementary science methods course using a reflection orientation. Journal of Science Teacher Education, Vol.8, No.3, 153-166. 1997

[23] L. Avraamidou. Prospective elementary teachers' science teaching orientations and experiences that impacted their development. International Journal of Science Education, Vol.1, 1-27. 2012. 
[24] P. Brown, P. Friedrichsen, S.K. Abell. Do beliefs change? Investigating prospective teachers' science teaching orientations during an accelerated post-baccalaureate program. Paper presented at the European Science Education Research Association (ESERA) Conference, Istanbul, Turkey. September, 2009.

[25] P. Brown, P. Friedrichsen, S.K. Abell. The development of prospective secondary biology teachers' PCK. Journal of Science Teacher Education, Vol.24, No.1, 133-155. 2013.

[26] M. Käpylä, J. Heikkinen, T. Asunta. Influence of content knowledge on pedagogical content knowledge: The case of teaching photosynthesis and plant growth. International Journal of Science Education, Vol.31, 1395-1415. 2009.

[27] B.C. Konopak, J.E. Readence, E.K.. Wilson. Pre-service and in-service secondary teachers' orientations toward content area reading. Journal of Educational Research, Vol.87, No.4, 220-227. 1994.

[28] C. Robson. Real world research: A resource for social scientists and practitioner-researchers (2nd ed). Oxford, UK: Wiley-Blackwell. 2002.

[29] L. Blaxter, C. Hughes, M. Tight. How to Research (3rd ed.). London: Open University Press. 2006.
[30] M. Denscombe. The good research guide for small-scale social research projects (3rd ed.). Berkshire: Open University Press. 2007.

[31] J.A. Luft. Changing inquiry practices and beliefs: the impact of an inquiry-based professional development programme on beginning and experienced secondary science teachers. International Journal of Science Education, Vol.23, No.5, 517-534. 2001

[32] F. Ogan-Bekiroglu, H. Akkoç. Pre-service teachers' instructional beliefs and examination of consistency between beliefs and practices. International Journal of Science and Mathematics Education, Vol.6, No.7, 1173-1199. 2009.

[33] J.D. Johnston, J.W. Whitenack. The use of videotape lessons to identify prospective teachers' initial beliefs concerning issues in mathematics and science teacher education. In: Annual Meeting of the Mid-South Educational Research Association. Knoxville, TN.1992.

[34] L.C. McDermott, P.S. Shaffer. Preparing teachers to teach physics and physical science by inquiry. In G. Buck, J. Hehn, \& D. Leslie-Pelecky (Eds), The role of physics departments in preparing K-12 teachers(pp.71-85). College Park, MD: American Institute of Physics. 2000. 